\title{
A Paks-Kalocsa híd várható, az erômú bővítéséhez kapcsolódó munkaerôpiaci és mobilitási hatásai
}

\author{
A Paksi Atomerőmü bővítését, illetve a Paks-Kalocsa híd építé- \\ sét érdemes párhuzamosan értékelni. A tanulmány megvizsgálja, \\ hogy milyen várható hatással lesz az infrastrukturális beruházás \\ az érintett járások munkaerőpiacára és mobilitására.
}

DOI 10.24228/KTSZ.2017.2.2

\section{Lukács Norbert - Dr. Tésits Róbert - Dr. Alpek B. Levente \\ Pécsi Tudományegyetem, Földrajzi Intézet \\ e-mail: lukacsnorbi91@gmail.com tesits.robert@gmail.com, alpeklevente@gmail.com}

\section{BEVEZETÉS}

A tanulmány aktualitása nagy részben a Paksi Atomerőmű tervezett bővítéséhez köthető. Egy olyan nagy volumenű beruházáshoz, amely megvalósulása során és azt követően is a társadalmi-gazdasági élet számos területén érezteti majd hatását. Az építkezéshez kapcsolódó munkaerő és (kezdetben) építőanyag szállítását megfelelő minőségű infrastruktúra nélkül nem vagy csak nehezen lehet biztosítani. A címben szereplö, a tervezőasztalon már létező híd a szállítási célokat szolgálja majd, hiszen a legközelebbi átjárási lehetőség jelenleg Szekszárdnál vagy Dunaföldvárnál található.

A tervezett híd két olyan különböző tervezési régió által érintett térséget kapcsol össze, ahol jelentősen eltérőek a gazdasági, illetve ezzel összefüggésben a munkaerőpiaci feltételek, ezen differenciák mind nagytérségi, mind települési szinten kézzelfoghatók. A jelen írás relevanciáját adja, hogy a Paks-Kalocsa híd e gazdaságilag különböző mértékben fejlett járások adottságai hatékonyabb kihasználása tekintetében hozhat kiegyenlítődést. Érdemes a hidat és az atomerőmü bővítését közös beruházásként kezelni, mert az energetikai szolgáltató nélkül a híd sem épülne meg. A nukleáris létesítményhez szükséges infrastrukturális fejlesztések pedig szükségszerüen viszonyulnak a híd meglétéhez.

Az ország dunai hídhálózatának egyik ismérve, hogy minél inkább közelítünk Budapesthez, annál gyakrabban találkozunk átkelést lehetővé tevő építménnyel. Az alföldi hidak tervezésénél fontos szempont volt, hogy olyan helyen létesítsék azokat, ahol képesek lesznek kiszolgálni az 1971-es településhálózat-fejlesztési koncepció célkitűzéseit (kettős gyürü létrehozása Budapest körül). Míg a belső gyürü a dunaföldvári hidat, a külső Baját érinti. A két település távolsága mintegy száz kilométer, amely közel egyórás közúti menetidőnek felel meg. Az említett két híd között az ezredfordulót követően újabb átkelő épült Szekszárdnál. A további igények hatékonyabb kiszolgálása érdekében 2001-ben egy ÉNy-DK és DNy-ÉK irányú tranzitvonal létrehozásának szükségességét állapították meg, amelynek metszéspontja Dunaújváros körül volt. A helyszínválasztást támasztja alá [3] legrövidebb távolságok elvére épülő modellje is.

A közgazdasági-közigazgatási és a területfejlesztési szakirodalmak ma már egyre inkább összekapcsolják a piac és az infrastruktúrafejlesztés fogalmát. A területfejlesztési gyakor- 


\section{Közlekedésgazdaság}

latban - mivel minden település, régió eltérő tulajdonságokkal, adottságokkal rendelkezik - nem lehet „azonos módon” fejleszteni. A körültekintő tervezés ezért legalább olyan fontos a közlekedési infrastruktúra-fejlesztés során, mint az építés vagy az üzemeltetés. Elfogadva azt a tézist, hogy a hatékony piacgazdaság fontos pillére a korszerü infrastruktúra, érdemes megemlíteni, hogy melyek azok a feltételek, amelyeknek egy beruházásnak meg kell felelni. Ilyen többek között a verseny kiszolgálása, a piac szereplöinek informálása (döntéseiket ezen információk függvényében hozzák meg), az erőforrások átcsoportosításának lehetősége, intenzív kapcsolatok létrejöttének igénye, valamint hogy a piaci „tranzakciós” kapcsolatok lehetőleg a legkisebb költség- és időigény mellett valósuljanak meg [2]. E tekintetben azonban a tervezett híd a penteleinél vélhetően célirányosabban képes kiszolgálni a vizsgált térség keleti területeinek, illetve Paks településnek az összeköttetését, lehetővé tenni a folyamatos munkaerőpiaci célú ingázást.

Habár a jól megtervezett és kiépített infrastruktúra gazdasági és társadalmi fejlődést indikáló potenciálja jelentős, de az ilyen irányú fejlesztéseknek nem feltétlenül csak pozitív hatásai léteznek. A probléma pedig a terület lehatárolásában rejlik. Ha a vonalas intézményeket makroszinten vizsgáljuk, akkor a sok pozitívum mellett szinte elhanyagolhatók a negatív hatások. Azonban települési szinten gyakorta fordítva jelentkeznek ezek az impulzusok. Minél kisebb területegységet vizsgálunk, annál inkább úgy tűnik, hogy az egyensúlyteremtő-képesség alig valósul meg. Probléma forrása lehet továbbá, hogy, ha egy hely megközelíthetősége javul, akkor a javak nem csak könnyebben jutnak ki a piacra, de a beérkező, esetleg jobb, olcsóbb, termékek kiszoríthatják a helyi termelőket. A munkaerőpiacra gyakorolt hatás sem elhanyagolható, hiszen a munkavállalók mobilitásának növekedésével, nagyobb esélylyel hagyják el a térséget [2]. Már csak azért is, mert a mobilitás egyre inkább a munkavállalók rugalmasságához hozzátartozó alapfeltétel kell, hogy legyen, különben kiszorulnak a munkaerőpiacról. A nagyobb vállalatok, gazdasági súlyuknak és anyagi forrásaiknak köszönhetően, a munkavállalókat képesek távoli településekről is magukhoz vonzani. Ez azonban csak akkor va- lósulhat meg, ha a munkaképes állomány partner ebben a folyamatban. A munkavállalóknak ilyenkor két dolgot kell mérlegelniük: vagy elköltöznek egy, az új munkahelyükhöz közelebbi településre, vagy vállalják a napi szintű ingázást. A második lehetőség esetén számolni kell az utazási idővel és az erre fordított költségekkel is [6].

A legfontosabb célunk, hogy megvizsgáljuk a Paks-Kalocsa híd várható munkaerőpiaci hatásait. E célkitűzés az alábbi részcélokon keresztül valósul meg. A keresleti oldal értékelő elemzése azért kiemelt fontosságú, mert ennek segítségével mérhető fel az egyes járások, illetve a leginkább érintett települések mobilitást befolyásoló hatása. A tanulmány feltárja azokat a faktorokat, amelyek jelenleg befolyásolják a települések munkaerőpiaci különbségeit, majd ezekre a tényezőkre építve értékeli a lehetséges változásokat. Természetesen a kínálati oldal elemzése is fontos, így indokolttá vált a társadalmi mobilitás szubjektív és objektív tényezőinek értékelése. A feltárt mobilitási tényezők függvényében egy hipotetikus modell segít a híd várható mobilitási-munkaerőpiaci hatásait ábrázolni. Teszi ezt - elsősorban geo-informatikai és statisztikai módszerek segítségével - részben az utazási idők, részben pedig az álláskeresési mutatók feltételezhető változásainak feltárásával.

\section{KUTATÁSI MÓDSZEREK}

A tanulmány elkészítéséhez a közgazdasági és geográfiai szakirodalmak mellett szekunder forrásként szolgáltak a vonatkozó terület- és településfejlesztési dokumentumok, amelyek segítségével a szerzők betekintést nyerhettek abba, hogy a különböző területi szintü közigazgatási egységek hogyan viszonyulnak a beruházáshoz. Ennek szükségességét támasztja alá az a tény, hogy a közlekedési infrastrukturális fejlesztések legtöbbje - akár a jelen vizsgálat tárgyát képező hídberuházás is - több évtizedre befolyásolhatja a térségek gazdasági helyzetét. A települések munkanélküliségét a munka.hu honlap statisztikáinak elemzésével végeztük. A 2015-ös foglalkoztatási adatok havi bontásban történő elemzésénél azok átlagolása vált szükségessé, mivel az érintett települések munkavállalóinak jelentősebb része a számottevő szezonális hatással jellemezhető 
mezőgazdasági, illetve építőipari szektorban foglalkoztatott. Az egyéb indikátorok (pl. oktatási statisztikák) forrása a Központi Statisztikai Hivatal 2011-es adattára (www.ksh.hu).

$\mathrm{Az}$ adatok térbeli megjelenítéshez az ArcGIS 10.2.2-es szoftvert használtuk. Az Open Street Map 2016.07.01-es állapota szerint a létrehozott poligonokat megfeleltettük a települések azon részeinek, amelyeken feltehetően munkavállalók/álláskeresők laknak. A szilárd burkolattal ellátott utakat térinformatikai szoftverrel szintén feldolgozhatóvá tettük. A területek elérését minden esetben a települések mértani közepétől számítottuk, így kiküszöbölve azt a problémát, hogy egyes helyeken a nagyobb népsürüség miatt több munkavállaló élhet. Fontosnak tartottuk, hogy az időbeli elérhetőség kapcsolódó értékei a modellben pontosan ${ }^{1}$ szerepeljenek, így az utakat lebegöpontos „float” adattípusban rögzítettük. A „minutes” attribútum létrehozásához az ArcCatalog programot használtunk. A fenti adatok létrehozása és kiszámítása után egy Network Dataset-et hoztunk létre, amely tartalmazza az atomerőmü helyszínét, az utakat, valamint a településeket. Mivel a Paks-Kalocsa híd még nem épült meg, így a pontos koordináták hiányában a fellelhető legjobb felbontású tervdokumentum alapján határoztuk meg a helyszínt a térinformatikai rendszerben.

A mobilitási fok meghatározására több módszert alkalmaztunk. Ezek az eljárások egymást kiegészítve adnak komplex képet a várható térbeli hatásokról. Az első az adott járáshoz tartozó foglalkoztatási központ munkaerőpiaci „szívóerejét" mutatja. A második módszer a mobilitáshoz szükséges közlekedési eszközöket vizsgálja, amely két összetevőből áll. A településen élő munkavállalók száma és az itt regisztrált személygépkocsik hányadosa által összehasonlíthatók a települések. Ugyanakkor a közösségi közlekedés elemzése is fontos információkkal szolgál, amelynek statisztikai alapját a Volán Zrt. által üzemeltetett menetrendek.hu adta. Fontos megemlíteni, hogy az eljárás csak a foglalkoztatási központok és a vonzott települések kapcsolatát vizsgálja.

A harmadik módszer a mobilitási fokok átlagára épül (a továbbiakban MFÁ [1],[7]), egy olyan többváltozós modellre, amelynek a segítségével a megfelelő pontossággal lehet ábrázolni, hogy az egyes településen élőknek milyen mobilitási lehetőségei vannak. Több paraméter szükséges a precíz eredmények eléréséhez, viszont az így kapott számok által települési szinten válik értékelhetővé a munkavállalói mobilitási készség, illetve képesség mértéke. Az input adatok empirikus vizsgálatainkban is használt primer források mellett a menetrendek.hu és az utvonaltervezo.hu oldalakról származnak. A hipotetikus modell többek között az MFÁmódszer alapján számolja ki a települések mobilitási lehetőségeit, amelyben az atomerőmü helyszíne szolgált foglalkoztatási központként. Jelenleg még nincs pontos információ arról, hogy milyen közösségi közlekedési útvonalakat hoznak létre a tervezett híd megvalósítását követően, ezért ezt a hiányt pótolni kellett, mégpedig az atomerőmü jelenleg használt menetrendje alapján.

Az empirikus vizsgálatot online és személyes kérdőívek segítették. Ezek célcsoportjai az érintett járások polgármesterei, akik a településfejlesztéssel kapcsolatos attitűdről, úthálózatáról, a beruházásban való részvételi lehetőségeiről, annak munkaerőpiaci hatásairól mondtak véleményt. A 134 lakossági online kérdőív hasonló strukturális felépítést követett. Az MFÁ-hoz szükséges adatok alapját a két járás összes településéről 5-5 (a járási székhelyeken 10-10), összesen 180 munkavállaló által adott válaszok adták. A kérdőív fóbb kérdéscsoportjai vizsgálták a közlekedési eszközök rendelkezésre állását és a munkavállalók ingázási hajlandóságának szubjektív tényezőit is.

\section{EREDMÉNYEK}

\subsection{A híd tervezett helyszíne és hatótá- volsága}

A Dunán átívelő szerkezet telepítési helyét még nem határozták meg pontosan, ahogy azt sem, hogy a bekötőutak hol csatlakoznak az első- és másodrendű utakhoz. A müszaki specifikációk ezzel párhuzamosan még elökészületi fázisban vannak, konkrétumokat e tekintetben nem lehet meghatározni. Tervek azonban már vannak, ahogy ezzel kapcsolatos 
szakmai egyeztető fórumok is. A tervezők három lehetséges nyomvonalat mutattak be (Géderlak és Ordas, Foktő és Dunaszentgyörgy, valamint Gerjen és Bátya között), és ehhez öt különböző hídtípus vázlatos ábráit prezentálták. A részletes konzultáció során megvitatták, hogy - különböző szempontok alapján - melyik az optimális párosítás. Az előnyöket és hátrányokat figyelembe véve a szakmai bizottság úgy döntött, hogy az ideális választás a Foktő és Dunaszentgyörgy közötti útvonal lenne, amely a Duna jobb partján Dunaszentgyörgytől délre csatlakozna a 6-os számú föúthoz, ezzel kapcsolatot teremtve Pakssal. A Paksi Atomerőmü Építészeti Osztályán megismert mérnöki szempontok alapján, már a geográfia aspektusából is vizsgálhatóvá vált a híd.

Az első számú nyomvonal Paks északi részén csatlakozik az országos közúthálózathoz. Nagy elönye, hogy Pakshoz ez lenne a legközelebb, viszont hátránya, hogy az atomerőmütől északra található, így az építés során több kockázati tényező is felmerülhet. Alacsony vízállásnál a Duna nem képes kielégítően hüteni a reaktorokat, és az építkezés során előfordulhat, hogy úgy befolyásolja a folyó vízhozamát, hogy az már veszélyes lehet az üzemelő erőmüre. A Pakson élők számára - kizárólag személyközlekedési szempontból - ez a legjobb választás.

A második számú nyomvonal ideális távolságban van a két járási központtól, valamint az atomerőmütől is délre helyezkedik el, tehát a két építkezés térben sem akadályozná egymást. Hátránya, hogy a hídfőkhöz képest messze találhatók a már kiépített közutak, így ebben a verzióban lenne szükség a legtöbb új út építésére. Az építés szempontjából a mérnökök egy része ezt az útvonalat tartja a optimálisan kivitelezhetőnek, így e nyomvonal megvalósulása a legvalószínübb.

A harmadik verzió legnagyobb hátránya, hogy távol esik mindkét járási székhelytől.

Térinformatikai vizsgálatainkat arra alapoztuk, hogy a híd Dunaszentgyörgy és Foktő között helyezkedik majd el. A lakossági, valamint a polgármesterek által kitöltött kérdőívek alapján is ez az ideális helyszínválasztás. Mivel az atomerőmű bővítése és a híd megépíté- se között ok-okozati összefüggés áll fenn, így a következők föleg azt vizsgálják, hogy az az erőmüvet mennyivel „hozza közelebb” a munkavállalók lakóhelyéhez.

A Kalocsai járásban található 51-es számú út, valamint a környező településeket érintő négy számjegyü utak $(5106,5308,5312)$ rossz állapotúak, a közlekedés sem komfort, sem idő szempontjából nem nevezhető ideálisnak. A Magyar Közút Nonprofit Zrt. „Komplex útfelújítási program"-ja alapján az említett szakaszokon bizonytalan ideig nem várható javulás. Ennél lényegesen jobb állapotúak a Tolna megyei utak, (különösen a 6-os számú föút). A munkavállalók elsősorban ezt preferálják, még úgy is, hogy a nagyobb távolságok miatt az utazási költségek is magasabbak.

Mivel a leendő híd a Paksi járás munkavállalóinak életét napi szinten nem befolyásolja, így a vizsgálatok elsősorban a Kalocsai járás településeit érintik. Az atomerőmű bővítése több ezer munkavállalóra lesz hatással. A napi ingázás szinte elkerülhetetlenné teszi a híd használatát. A továbbiakban tehát hipotetikus állapotról beszélünk, hiszen a beruházás még nem kezdődött el.

A jelen állapotok szerint a Kalocsai járásban élők, akár északról, akár délről közelítik meg a bővítés helyszínét, az több mint fél órát jelent. Az utak rossz minősége ezt az időt tovább növeli. E tekintetben Újsolt és Hajós települések vannak a legrosszabb helyzetben, ugyanis e községek találhatók a legmesszebb az erömütől. Mindössze néhány olyan település található a járásban, amely a 30 perces zónán belül fekszik. Solt relatíve kedvező helyzete a dunaföldvári híddal való közvetlen kapcsolatával magyarázható.

A 1. ábra jobb oldalán a híd hatása digitalizált formában már látható, várható hatása szembetűnő, mivel a Kalocsai járás településeinek lakói rövidebb idő alatt jutnak el az atomerőműhöz. Kalocsa települése a helyszíntől függően a 10 és 20 perc közötti intervallumba kerül, ez megegyezik Paks elérhetőségével, a munkavállalók lényegesen jobb feltételek mellett érhetik el a nagyberuházás által lét- 
rejövő munkahelyeket. További települések is részesülnek e pozitív hatásból, szinte mindegyik a 30 perces útidővel elérhető intervallumhatárérték alá kerül. Belátható, hogy az új híd vonzáshatára valahol Solttól délre található. Az itt lakók eldönthetik, hogy melyik útvonalon szeretnének átjutni a Dunán. A Kalocsai járásban élők a hídnak a város életére gyakorolt hatásával szemben, inkább az alsóbbrendü és helyi utak felújítását, valamint egy kompkikötő megépítését szorgalmazzák. A híd reális hatótávolságát Dusnok mellett állapítottuk meg, amely megközelítőleg 27 percnyi közúti elérhetőségnek felel meg (2. ábra). A Kalocsai járásban tehát - földrajzi adottságaik okán három kivételével (Dunatetétlen, Solt, Újsolt) a települések munkavállalóinak/álláskeresőinek jelentős része profitálhat a tervezett beruházásból abban az esetben, ha leendő munkahelyük a Paksi járásban lenne.

\subsection{A híd ko̊rnyezetében élök mobilitása}

A mobilitás vizsgálata előre jelezheti, hogy a munkavállalók milyen mértékben és intenzitással fogják használni a hidat. Amennyiben a helyi munkavállalóknak jelenleg sincs nagy affinitásuk arra, hogy a lakhelyüktől távol dolgozzanak, úgy a híd valószínűsíthetően kevésbé lehet kihasznált. A járásokban található foglalkoztatási központok [5] és az általuk vonzott települések kapcsolatát számos megközelítés szerint lehet értékelni. Egy adott járás gazdasági vonzereje több összetevőből adódik. Az egyik, hogy hány aktív korúnak képes munkát adni. A magasabb bérek, a jobb infrastruktúra és a kedvezőbb ingázási lehetőségek a távolabbi településeken élőket is képesek vonzani. Amennyiben a járási foglal-
2. ábra: A híd várható reális hatótávolsága

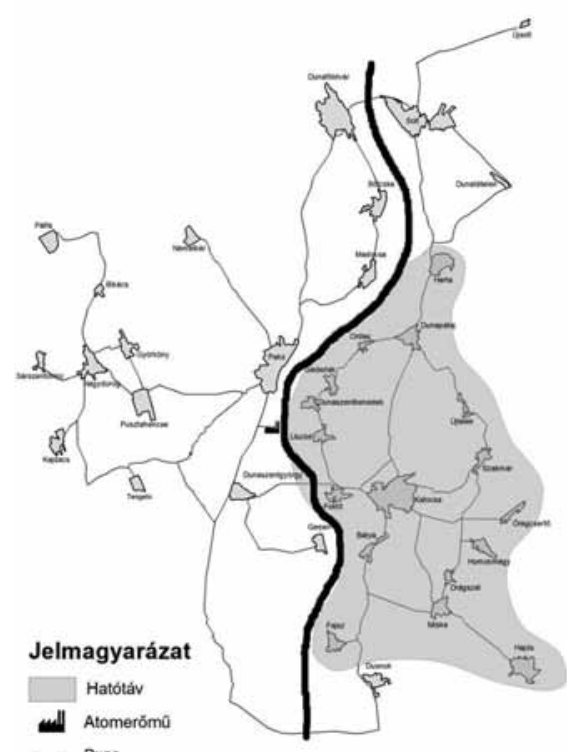

- Duna 


\section{Közlekedésgazdaság}

koztatási központ a térség munkavállalóinak a legfőbb munkahelyet jelenti, az információból több következtetés is levonható. Az első, hogy a foglalkoztatási központ jó lehetőségeket biztosít mindenki számára, és feltételezhetően a városban megfelelö az infrastruktúra fejlettségi szintje. Ebben az esetben a gazdasági növekedéshez a feltételek adottak, ezért távolabbról is megéri ingázni. A szomszédos járásokban élők számára új lehetőségek nyílnak, amelyeket ki is használnak, ha ez pénzben és időben megéri nekik.

A második következtetés, hogy a foglalkoztatási központ gazdaságilag gyenge, viszont így is képes a járásban élőket munkával ellátni, mivel a helyieknek nincs lehetőségük elköltözni vagy ingázni. Az utóbb felvázolt forgatókönyvben magasabbak a munkanélküliségi ráták. Amennyiben a foglalkoztatási központ gyenge, és kevés munkahelyet képes csak biztosítani, az álláskeresők feltételezhetően új alternatíva után néznek, másik foglalkoztatási központba kényszerülhetnek ingázni. A vizsgált két járásban található négy foglalkoztatási központ közül kettő jelentős, kettő csak egy-egy települést képes vonzani (Paks: 12 település, Kalocsa: 15 település, Harta és Solt: 2-2 település). A két járásközpont gazdasági ereje országos viszonylatban átlagos. A munkavállalási korúak járásonkénti száma megközelítőleg 3535 ezer fő. Mobilitási indexük (a járáson belül élő munkavállalók és a járáson belül dol- gozó munkavállalók hányadosa) azonban már eltérö, míg a kalocsai oldalon ez a szám 0,88 , addig a paksi részen már csak 0,75 (3. ábra).

A 0,13-os különbségnek a Dunaföldváron élő 6092 fö „elveszítése” az oka. Dunaföldvár földrajzilag Paks és Dunaújváros között helyezkedik el, majdnem a két foglalkoztatási központ között félúton. A városban élőknek tehát a távolságokat nem kell mérlegelni, ezért más szempontok kerülnek előtérbe a munkahelyválasztáskor. A járási mobilitási index alapján a Kalocsai járás sokkal előnyösebb helyzetben van, mert nem „veszít” nagy lélekszámú településeket. Ugyanakkor, a legdélebbi falvak Baja munkaerővonzó

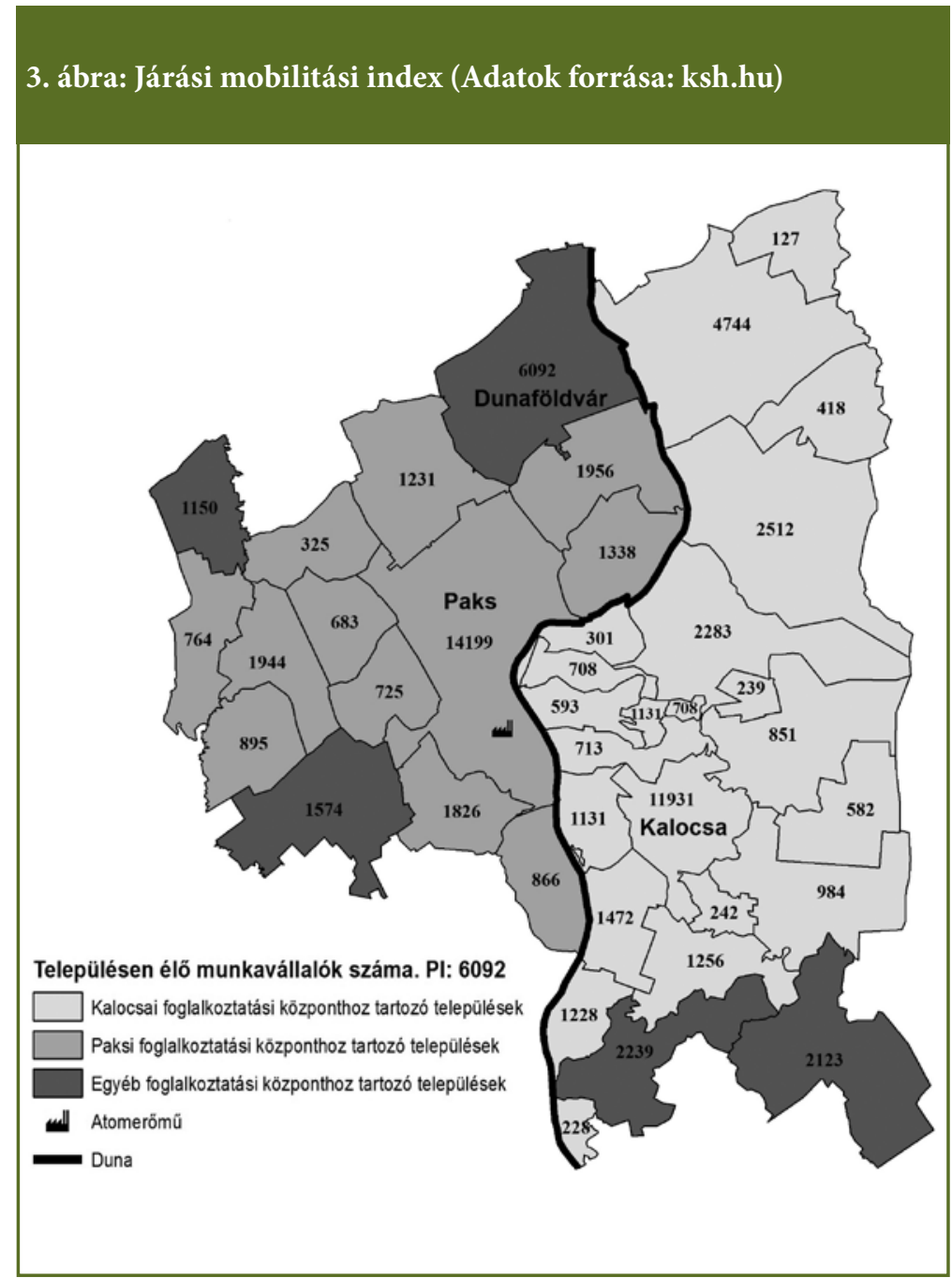


körzetéhez tartoznak [5]. Sükösd időben és távolságban is közelebb van ehhez a városhoz, így a Kalocsai járás munkavállalói racionális döntést hoznak, amennyiben az idő az elsődleges választási szempont. Hajós esetében viszont nem a távolság jelenti a fő befolyásoló tényezőt, hanem a közösségi közlekedés, mert kétszer annyi időbe telik eljutni Bajára, mint Kalocsára, személygépjármű esetében pedig húsz helyett harminc perc a menetidő. Ez az anomália betudható annak, hogy Baja munkahely-kínálati és bérezési spektruma lényegesen szélesebb körü lehetőségeket nyújt az embereknek, akik a napi ingázást „forintosítva” vállalják az utazást. A paksi oldalon megfigyelhető, hogy azok a munkavállalók lépik át a járáshatárt, akik az atomerőmütől távol laknak. Dunaföldvár, Pálfa és Tengelic szintén a legtávolabbi települések. A felsoroltak közül az utóbbi két község rendelkezik alacsony színvonalú közösségi közlekedési kapcsolattal az erömű irányába (4. ábra).

A közösségi közlekedés költsége, 1-2 fös használat esetén, kisebb, mint a személygépjármüé. Dunaföldvár példáján keresztül jól látszik, hogy miért is van Dunaújváros kedvezőbb helyzetben, mint Paks (4. ábra). Az autóbusz adta (mert vonatközlekedés nincs) lehetőségeket az emberek jobban ki tudják használni, ez költségráfordítás szempontjából szintén előnyösebb. Leggyakrabban e két település között jár a távolsági autóbusz, napi 64 alkalommal, amely önmagában véve is kiemelkedően magas értéket képvisel. A tizenöt percenkénti indulási idő megkönnyíti azoknak a munkába járását, akik váltott munkarendben dolgoznak. Dunaújvárosban több üzem is található, ahol lehetőség van éjszakai müszakban dolgozni. Ezek a gyárak sokak számára nyújtanak elhelyezkedési lehetőséget (gumi-, acél-, papíripar, textilüzem), ezért a két város között az autóbuszjáratok nagy száma hangsúlyossá teszi a 6-os számú föutat a Dunaújváros-Dunaföldvár-Paks-Dunaszentgyörgy útvonalon. Tolna megyében ezen az útszakaszon közösségi közlekedési eszköz jár a leggyakrabban, ami indikátora a naponta ingázók számának. A Kalocsai járásban szintén megfigyelhetö ez a trend, a sürün közlekedő autóbuszjáratok az észak-dél irányú útvonalakra koncentrálódnak. Ennek oka, hogy a Kalocsától keletre, illetve nyugatra található települések alacsonyabb lélekszámúak, valamint a falvak elhelyezkedése miatt nem alakult ki ezzel párhuzamos úthálózat.

A személygépjármü-állomány és a munkavállalási korúak összevetéséből több dologra lehet következtetni. A két járás közötti fö különbség, hogy a paksi oldalon alacsonyabb az autók munkaképes korú lakossághoz viszonyított aránya. A magas személygépkocsi-állománynyal rendelkező települések közül Dunaföldvár, Györköny és Paks városa emelhetö ki. A járásban továbbá ezek rendelkeznek a legalacsonyabb álláskeresési rátával (10. ábra), így összefüggés fedezhető fel a két tulajdonság között. Az átlagos álláskeresési mutató 4\%-nál alacsonyabb, ezért jó okunk van feltételezni, hogy ezen három településen a kiemelkedő mobilitási lehetőségek szerepet játszanak a munkaerőpiac stabilizálásában. Sokkal homogénebb képet kapunk a Duna bal partján.

A Kalocsai járásban jellemzően több háztartásban található személygépjármü, amely hiánypótló a térség kedvezőtlen közlekedési adottságainak ellensúlyozásában. A hátrányos elhelyezkedést tovább csökkenti, hogy a távolsági járatok is gyakoribbak, mint a paksi oldalon. A mobilitás e szintjén a Kalocsai járás ismét kedvezőbb értékeket mutat, ennek ellenére magasabbak a munkanélküliségi ráták. Az itt élők napi ingázására adottak a lehetőségek, azonban az eddigi módszerek csak statisztikai alapon vizsgálták ezt a kérdést, a lakossági attitűd szubjektív elemeit a 3. és 4. ábra nem mutatja.

A lakosság hozzáállása több összetevőre bontható. Tételezzük fel, hogy egy adott községben élők munkát vállalnának, de nincsen hova, vagy mivel eljutni. Ez fordítva is igaz lehet, jó adottságokkal rendelkezik egy település, azonban a környezetében élők nem szívesen vállalják az ingázással járó időveszteséget vagy költségeket. A probléma értékelésében segít a korrigált mobilitás index ${ }^{2}$ [7] (5. ábra). A rendszerben megjelenik a mobilitási hajlandóság, mint a lakossági felmérésekből származó ösz-

${ }^{2}$ A Mobilitási Fokok Átlaga modell, MFÁ-modell megmutatja, hogy - feltételezve a vizsgált ingázási relációban az értékelt közlekedési eszköz teljes körü rendelkezésre állását (azaz, hogy mindenki számára elérhető) - mennyire kedvező az adott (vonzott település) község/város utazási idők és költségek tekintetében vett elérhetősége. A nagyobb értékek jobb mobilitási lehetőségekre utalnak. 


\section{Közlekedésgazdaság}

szetevő. A fentebb bemutatott mobilitási ábrákkal párhuzamba lehet állítani a 9. ábrát. Az atomerőműtől való ingázási távolság komoly befolyásoló tényező. A kalocsai „gyürü”-ben kirajzolódnak a térség munkavállalóinak lehetőségei; a város képes arra, hogy a közeli falvakból vonzza a munkavállalókat.

Összességében megállapítható, hogy a két járásban nem található olyan szubjektív tényező, amely meggátolná, hogy az emberek munkahelyüket megváltoztatva napi szinten ingázhassanak. Belátható, hogy a térséget jellemző magasabb munkanélküliség okai nem a munkavállalói attitüd vagy közlekedési lehetőségek hiánya.

\section{4. ábra: Közlekedési kapcsolatrendszerek a foglalkoztatási központok és az általuk vonhzott települések között (Adatok forrá- sa: menetrendek.hu, ksh.hu)}

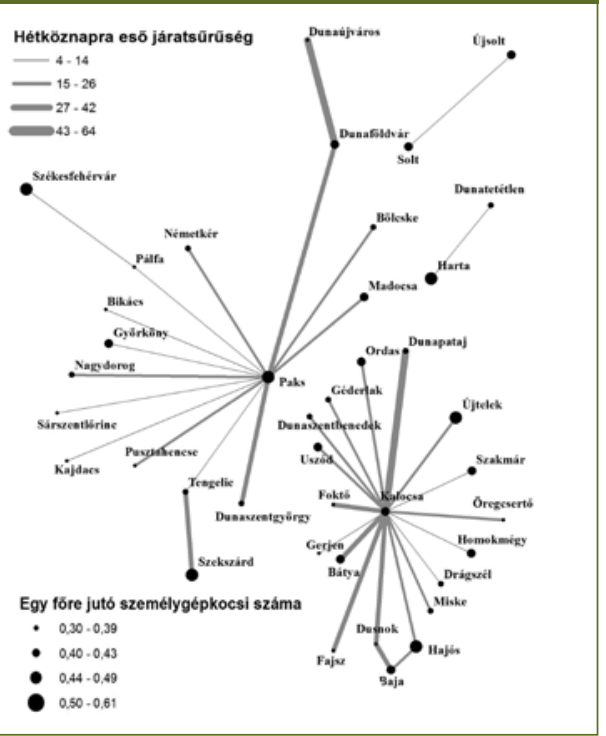

A mobilitásvizsgálat eddigi eredményei a 2015-ös év állapotát mutatták. A két járásban található foglalkoztatási központok és a vonzott települések viszonya megmutatta, hogy milyen alapvető különbségek találhatók a Duna két partján. Az eltérő gazdasági viszonyok differenciáló hatása megkérdőjelezhetetlen. Bár több szempontból is összehasonlítható a két járás, viszont a fent említett különbségek miatt nem kapunk homogén környezetet, azonos feltételekkel. Azok a foglalkoztatási köz-

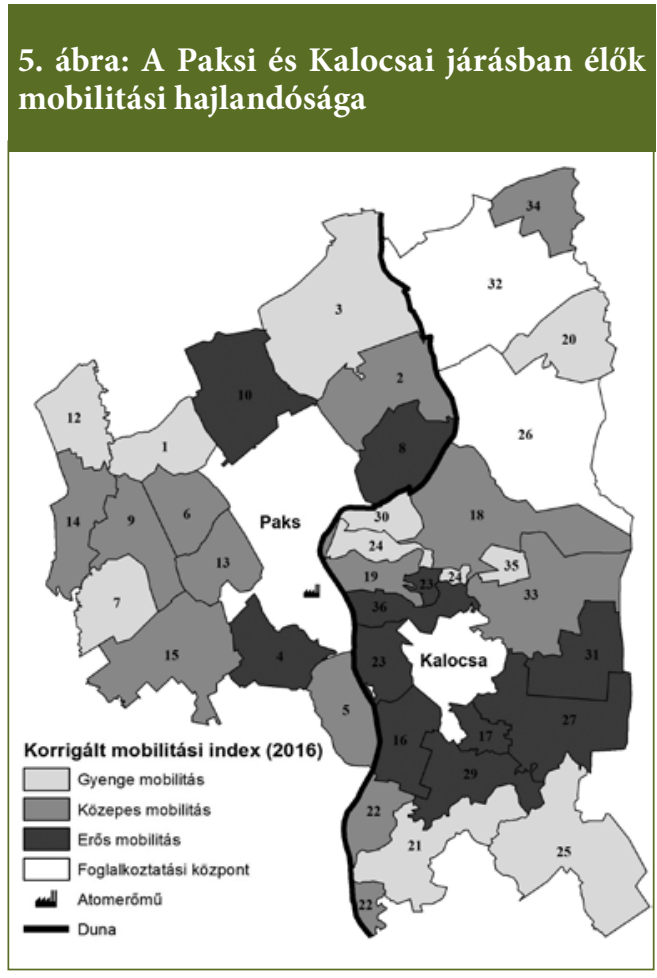

1: Bikács, 2: Bölcske, 3: Dunaföldvár, 4: Dunaszentgyörgy, 5: Gerjen, 6: Györköny, 7: Kajdacs, 8: Madocsa, 9: Nagydorog, 10: Németkér, 11: Paks, 12: Pálfa, 13: Pusztahencse, 14: Sárszentlörinc, 15: Tengelic, 16: Bátya, 17: Drágszél, 18: Dunapataj, 19: Dunaszentbenedek, 20: Dunatetétlen, 21: Dusnok, 22: Fajsz, 23: Foktő, 24: Géderlak, 25: Hajós, 26: Harta, 27: Homokmégy, 28: Kalocsa, 29: Miske, 30: Ordas, 31: Öregcsertő, 32: Solt, 33: Szakmár, 34: Ujsolt, 35: Újtelek, 36: Uszód

pontok, amelyek csak egy települést képesek vonzani, nem rendelkeznek ugyanakkora gazdasági súllyal, mint egy, több ezer munkahelyet teremtő város.

A 6. ábra megmutatja, hogy milyen a mobilitási helyzet abban az esetben, amennyiben központként az atomerőmüvet jelöljük meg. Itt ismét megjelennek azok a hatások, amelyek a munkaerőpiac álláskeresési statisztikáit is alakították. A Duna egyfajta falként zárja el a Kalocsai járás munkavállalóit az atomerőmütől, a folyón történő átkelés korlátozott, ezért e településeken élők mobilitási foka nullához közeli értéket vesz fel. Mivel a napi ingázás időbeli és pénzbeli költségei - a korábbiakban vizsgált helyzethez képest - ugrásszerüen megnőttek, így szinte kivétel nélkül kiesnek az erőmü von- 


\section{Közlekedésgazdaság}

záskörzetéből. Egyedül a dunaföldvári hídhoz közel eső Solt települése ér el közepes mobilitási szintet, amelyhez hasonlóval a Pakstól legtávolabbra eső Pálfa község rendelkezik. A Paksi járás többi települése a kedvező közlekedési lehetőségeknek köszönhetően erős mobilitással bír.

\subsection{A híd feltételezhető hatásai a térin- formatikai modell alapján}

A járások mobilitási helyzetének vizsgálati eredményei, az értékelt faktorok és feltárt összefüggések fényében a következőkben egy hipotetikus modell érzékelteti a várható munkaerőpiaci változásokat. A híd nélküli erőműbővítés a mobilitási viszonyokat nem módosítaná jelentősen: a Kalocsai járás továbbra is elszigetelt lenne, a Paksi járásra gyakorolt hatása mérsékelt. Ugyanakkor az atomerőmü bővítése nélkül valószínüleg nem épülne meg a híd. Mivel a beruházásnak elsősorban az út-idő távolságokra lesz befolyása, ezért ilyen irányban célszerü vizsgálni a feltétezhető hatásokat. Azáltal, hogy a Duna izoláló jellege megszünik, a kelet-nyugat irányú útvonalak száma bővülne, a bal parti települések számára új lehetőségek nyílnának. A munkanélküliséget korábban befolyásoló faktorok közül a folyó hatása minimalizálódik, kiegyenlítettebb térszerkezetet eredményezve, ahol az atomerőmütől való távolság válik a legfontosabb tényezővé. Az így kialakuló kedvezőbb közlekedési helyzet miatt további, a piaci szférában realizálódó beruházások potenciálja is megnőhet. A híd így multiplikátor-hatást képes kifejteni a térségre, egyfajta katalizátorként funkcionálhat.

\section{6. ábra: A mobilitási fokok egyenlőtlenségei a híd nélkuil (2016)}

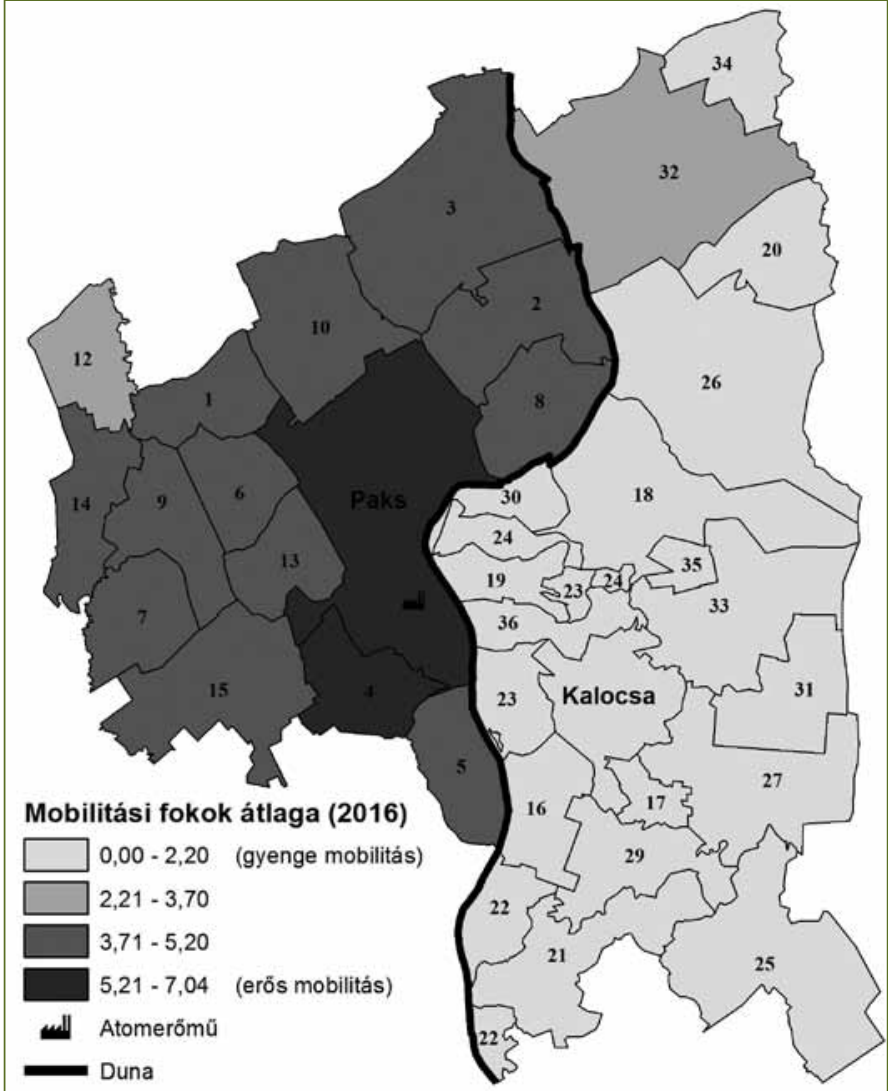

Az elemzett mobilitási fok a híd révén a bal parti településekben jelentősen nő (7. ábra). A pozitív változás alapja, hogy a helyi munkavállalók alapvetően rugalmasan kezelik az ingázás kérdését, így annak szubjektív feltételrendszere többé-kevésbé adott. A korrigált mobilitási index alapján azok a települések profitálhatnak leginkább a hídból, amelyeknek Kalocsa városa jelentette az elsődleges foglalkoztatási központot. Természetesen nem elhanyagolható a járási központ helyzetének változása sem, hiszen az itt élő több ezer munkavállaló számára szintén elérhető távolságba kerül az atomerőmü. A modell alapján megállapítható, hogy az áramszolgáltatótól legtávolabb eső települések mobilitási szintje továbbra is alacsony maradhat. Ez összhangban áll a híd reális hatótávolságával, amely a modell következetességére is utal. Habár a két járás „közelebb került” egymáshoz, még így sem jellemezhetők kiegyenlített mobilitási fokokkal. 


\section{Közlekedésgazdaság}

\section{7. ábra: A híd várható, mobilitásra gyakorolt hatásai (mobilitási fokok átlaga 2015-2020)}
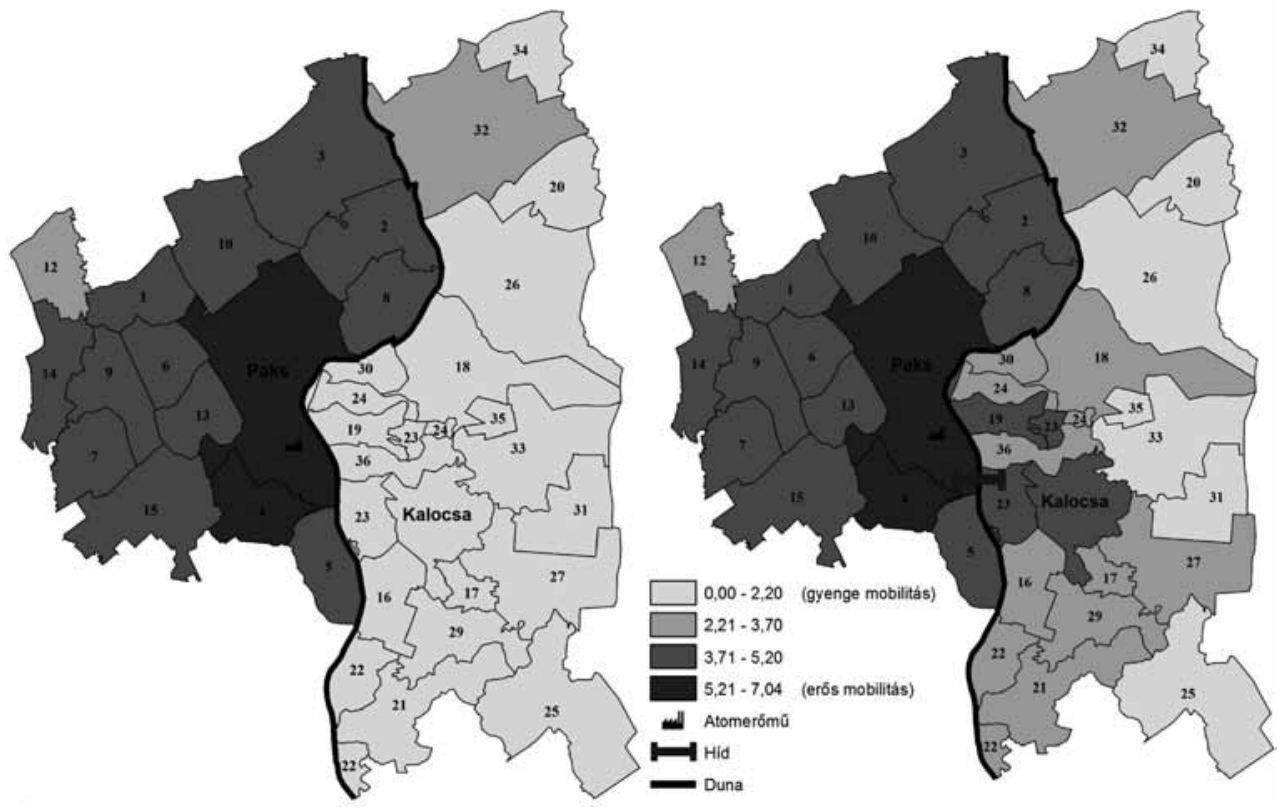

Ennek legföbb oka, hogy az 51-es és az 53-as számú utak állapota rossz, illetve a Kalocsai járás kedvezőtlen településszerkezeti adottságai sem változnak. Bár a vizsgált térség keleti fekvésü településeit, közlekedésföldrajzi helyzetük miatt, a híd csak kis mértékben érinti, számukra még így is kiugrási lehetőségnek tekinthető a beruházás. Az 1505/2016.

IX.21. Kormányhatározat alapján a miniszterelnökség hazai forrásokból kívánja előteremteni a híd anyagi megvalósításának feltételeit. A tervek szerint az építkezés 2018. I. negyedév és 2020. II. negyedév között valósul meg.

$\mathrm{Az}$ atomerőmű bővítésének munkaerőigénye iskolai végzettségtől függetlenül a munkaerő-

8. ábra: $A z$ atomerőmű bővítésének várható munkaerőigénye 2015-ös becslések alapján (Forrás: Paks II.)

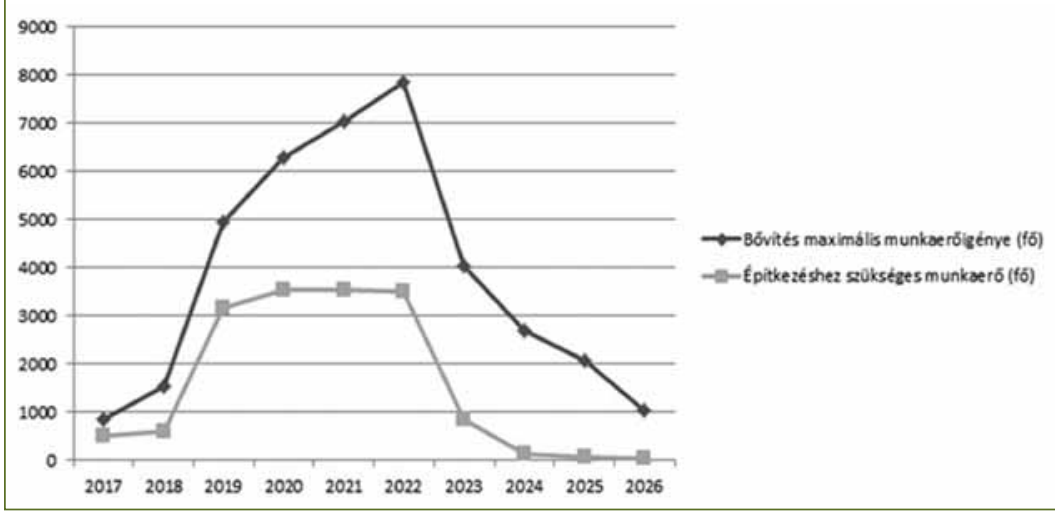

állomány legtöbb csoportját érinti. Az államközi szerződés alapján a magyar félnek a bővítés humáneröforrás-igényét elsősorban a kivitelezési folyamatokból érdemes kihasítania. Ez az egyszerü földmunkálatokat is magában fogalja, amely feladatkörhöz nem szükséges magasan képzett állomány. Így az új 


\section{Közlekedésgazdaság}

közlekedési kapcsolat minden bizonnyal lehetöséget kínál azok egy része számára is, akik eddig tartósan kiszorultak a munkaerőpiacról. Paks II. beruházás elkezdésétől a hálózatra kapcsolásig több ezer embert foglalkoztat majd. Az építkezés várhatóan 2017-ben kezdődik és optimális esetben 2026-ig tart. A hasonló volumenü beruházásokból kiindulva a foglalkoztatás csúcspontja a 2021-2022. évre prognosztizálható (8. ábra), amikor is a tervezett két új erőmüvi blokk munkálatai párhuzamosan zajlanak [4]. A 9. ábra érzékelteti, hogy hány álláskeresőnek kellene részt vennie a beruházások kivitelezésében ahhoz, hogy a település munkanélküliségi mutatója legalább egy százalékponttal csökkenjen. ábrán látható volt, hogy ez a térség a járási átlaghoz képest magasabb álláskeresési mutatóval rendelkezik. Valószínüsíthető azonban, hogy az érintett települések képesek legalább tíz fó álláskereső munkaerőpiaci integrációjára. Ez a szám minimálisnak tünik az erőmü építéséhez szükséges munkaerőigényhez viszonyítva. Érdemes külön kiemelni az Ordas-Foktő-tengely településeit, mivel itt a munkanélküliség optimális esetben akár $10-15 \%$-ot is csökkenhet. Amennyiben a fent említett községek képesek profitálni a beruházásokból, a Kalocsai járás munkaerőpiaca sokkal homogénebb térszerkezeti képet mutathat majd (10. ábra).
A kis lélekszámú települések - ebböl a szempontból - természetesen jobb helyzetben vannak, mivel alacsonyabb a munkavállalási korú népesség aránya, a jelölt érték eléréséhez kevesebb álláskeresőnek kell munkába állnia, a változás is látványosabb. A Kalocsai járás legnyugatabbra fekvő településeinek demográfiai, gazdasági statisztikái alapján az egy százalékpontos csökkenés reálisnak tünik. Érdemes ezt a térséget azért is kiemelni, mert valószínűleg innen kerülnek ki azok a községek, amelyek mobilitási foka a legnagyobb mértékben változhat. Feltételezve, hogy ezeken a településeken élő munkavállalók kihasználják a híd által kínált lehetőséget, egyes Duna parti települések zsákfalu-jellegéből adódó hátrányok jelentősen csökkenhetnek. A 4 .

\section{9. ábra: A munkanélküliség minimálisan egy százalékpontos csökkenéséhez szükséges munkaerö}

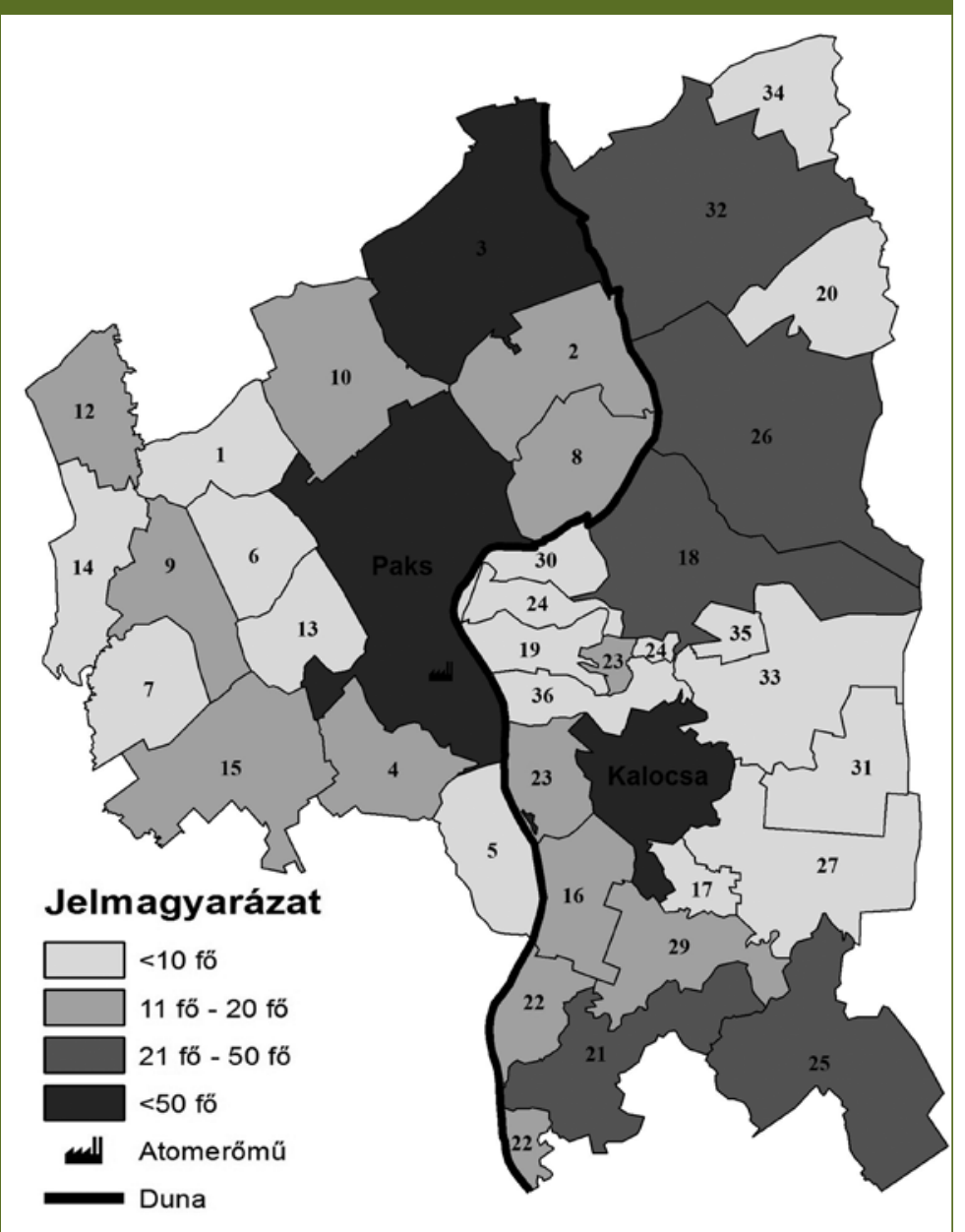




\section{Közlekedésgazdaság}

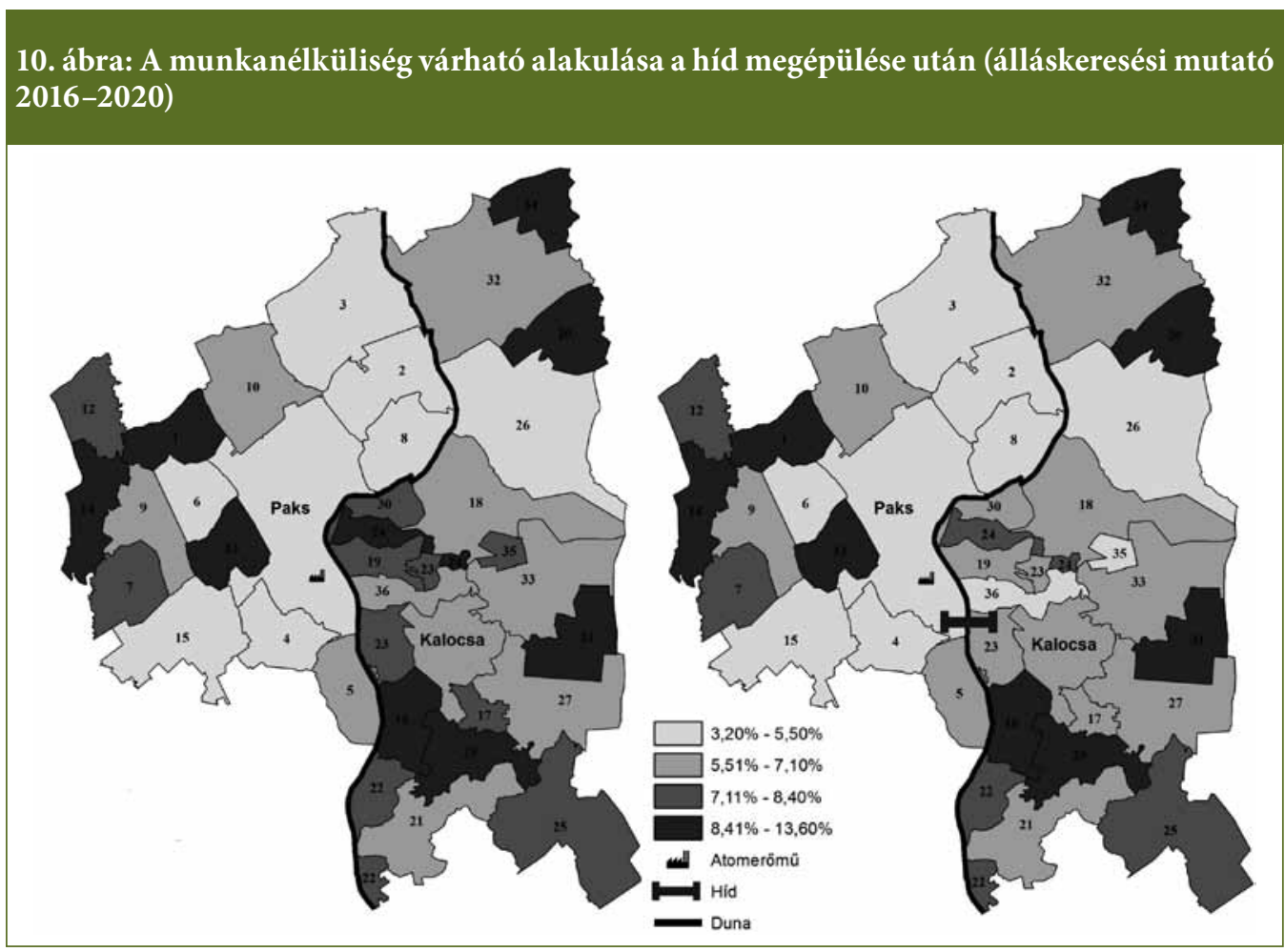

A modell alapján a Kalocsai járásból legalább 100-120 ember fog majd közvetlenül munkát vállalni a bővítéssel összefüggésben. Ez nagyjából megfelel a Foktőn található Glencore növényiolaj-elöállító üzem 2013-as bővítésének munkahelyteremtő értékével. A svájci cég 40 milliárd forintot szánt a magyar telephely bövítésére (napi.hu). Ezzel szemben a tervezett híd költségei alacsonyabbak. Bár a pontos költségvetés a vizsgálat időpontjában még nem ismert, a közelmúltban épített hidak összehasonlítási alapot nyújthatnak (M3 Polgár-Füzesabony: 69,5 Mrd Ft; Tisza-híd 14,7 Mrd Ft; M9 autóút 22,3 Mrd, ebből a híd költsége 9,3 Mrd, mno.hu). Érdemes hozzátenni, hogy az összehasonlítási alap nem lehet minden szempontból etalon, hiszen egy állami beruházásról és egy cég magánberuházásáról beszélünk.

A fent értékelt, várhatóan kedvező hatásokat a térségben élők véleménye is alátámasztja. A jelenlegi tervek szerint az atomerőmü építésének tervezett záró dátuma 2026, eddig a híd a beruházás közvetlen kiszolgálására szolgál. Az építés feltehetőleg 4-5 éves periódusában a kihasz- náltság egyértelmü, de a beruházás megtérülése a környező települések jövőképe szempontjából még nem látható. A térségben élők többsége már most arra számít, hogy a járások helyzetét pozitívan érinti majd a híd. Nem meglepő, hogy a Duna jobb partján élők kisebb érdeklődést mutatnak a híddal kapcsolatos fejlesztésekre, ugyanakkor a Kalocsa környékén élők sokkal több potenciált látnak benne. A munkavállalók, lakóhelyüktől függetlenül, a járásközponttól a legkisebb településen élőkig, számítanak a híd által kínált jövőbeli lehetőségekre. Jellemzően a diplomával és a szakmunkás-bizonyítványnyal rendelkezők érdeklődnek az ilyen irányú munkavállalás iránt. Ráadásul ők azok, akik leginkább illenek a Paks II. projekt építési és üzemeltetési profiljába.

\section{KO̊VETKEZTETÉSEK}

A tanulmány rámutatott, hogy a két beruházás (az atomerőmű bővítése és a Paks-Kalocsa híd megépítése) az érintett járások esetében nagy valószínűséggel előmozdíthatja a társadalmi-gazdasági fejlődést. Az ilyen nagyszabású 
fejlesztések több évre meghatározhatják a települések gazdasági és társadalmi viszonyait, így már az építkezés előtt érdemes megvizsgálni a várható hatásokat, hogy a beruházások optimálisan valósuljanak meg. Annál is inkább, mivel a híd a tervdokumentumok közül Bács-Kiskun megye területfejlesztési koncepcióiban jelenik meg hangsúlyosan, azonban a stratégia nem részletezi, hogy a lehetőséget milyen módon próbálják majd kihasználni. A paksi városfejlesztési koncepció elsősorban a térség munkaerővonzó képességének erősödésére hívja fel a figyelmet, azáltal, hogy a Duna által elválasztott terek közelebb kerülnek egymáshoz, tartós megélhetési lehetőséget biztosítva a Kalocsai járásban élők egy részének is.

A két járás munkaerőpiacát meghatározó faktorok összefüggésben vannak a természetföldrajzi adottságokkal, valamint a településstruktúrával. A Kalocsai járásban a Duna jelenléte a leginkább meghatározó befolyásoló tényező. A folyó elszigeteli a járást az atomerőmütől, és a kelet-nyugat irányú útvonalak kiépülését is meggátolja. Ezért a Duna partján lévő települések kedvezőtlen közlekedési adottságai miatt itt alakult ki a járás leghátrányosabb gazdasági helyzetü körzete; a munkanélküliség is ezen a területen a legnagyobb. Ezzel szemben, a Paksi járásban az atomerőmü távolsága jelenti a helyi munkaerőpiacot legnagyobb mértékben befolyásoló faktorát. $\mathrm{Az}$ energetikai vállalat több ezer embernek ad munkát, és azok a települések tudnak leginkább profitálni az áramszolgáltató közelségéből, amelyek időben és térben is közel találhatók hozzá. A paksi ipari park további munkahelyeket képes biztosítani, így nagytérségi összevetésben is iparosodott járásról beszélhetünk. A Kalocsai járásban főleg a mezőgazdaságra épülö iparágak fejlödtek, és ezek a vállalatok jelentik jelenleg is a legnagyobb üzemeket. Az itt dolgozó munkavállalók száma és a gyárak gazdasági súlya azonban nagyságrendben kisebb, mint az atomerőmű és beszállítói köre, valamint a paksi ipari park súlya.

A híd megvalósítására három lehetséges helyszínt határoztak meg. A tanulmány ismerteti a mérnöki és a lakossági véleményekkel is alátámasztott, optimális nyomvonalat. A térinformatikai modellt és az erre épülő ered- ményeket ennek függvényében ábrázoltuk. A híd ilyen feltételek mellett - további kalkulációkra alkalmas állapotban - jelentős mértékben változtathatja meg a két járás közötti közlekedési kapcsolatokat. A vizsgálat időpontjában Tolna megye és Bács-Kiskun megye között két híd található, ezért a Duna két oldalán fekvő települések között nincs jelentős ingázás. A híd a két járási központ közötti utazási időt legalább a felére képes csökkenteni. A Kalocsai járásban élő munkavállalók számára azonban sokkal fontosabb, hogy az atomerőmű elérhető távolságba kerül. A híd azonban még így sem lesz hatással minden településre. Az alkalmazott modell értelmében az új közlekedési kapcsolatot teremtő építmény reális hatóválsága 27 perc (közúti) utazási időnek felel meg.

A települések mobilitásának meghatározását $\mathrm{az}$ atomerőmü bővítéséhez érdemes kötni. Bár a Kalocsai járásban élők (szubjektív) mobilitási hajlandósága kedvező, a mobilitási fok (objektív+szubjektív) a rossz közlekedési viszonyoknak köszönhetően kifejezetten gyenge. Az itt élőknek ezzel szemben lenne affinitásuk, hogy a lakhelyüktől távolabb dolgozzanak. A Paksi járásban élő munkavállalók ingázási szokásait a híd nem befolyásolja. A modell alapján láthatóvá vált, hogy az építmény jelentős mértékben változtathatja meg a mobilitási viszonyokat. Az infrastrukturális beruházás eredményeképp a két járás sokkal kiegyenlítettebb térszerkezeti képet mutathat, és a Duna izoláló hatása is megszünik. Ezáltal a munkaerő-kínálatot az energiaszolgáltató-üzem közúti távolsága határozza majd meg.

$\mathrm{Az}$ atomerőmű bővítése során, munkahelyteremtő hatásának köszönhetően, a tervek szerint több ezer ember foglalkoztatása várható a térségben. A Paks II.-höz készített tervdokumentumokban szereplő becslésekből megállapítható, hogy hasonló volumenü atomenergetikai beruházások építési ideje - a komplex beruházás -2017 és 2022 között valósul meg. A kivitelezési folyamatok, elsősorban a földmunkálatok több ezer embernek adhatnak munkát. Tehát, iskolai végzettségtől függetlenül szükség lesz munkaerőre, 
amely lehetőséget kínál majd a képzetlenebb csoportok tagjai számára is. A 2015-ös álláskeresési statisztikákhoz képest több település érhet el akár 10-15\%-os munkanélküliségcsökkenést. A leginkább érintett települések éppen azok, amelyek a Duna izoláló hatása miatt korábban kedvezőtlen helyzetben voltak, tehát elsősorban Kalocsa és környéke profitálhat a beruházásból. A lakossági attitűd alapján az érintettek támogatják a fejlesztést, és kiugrási lehetőségként tekintenek a hídra. Hozzá kell tenni, hogy a híd további hatásának optimalizálása érdekében útfelújítások szükségesek. A jelenlegi közútfejlesztési tervek között nem szerepel ezen szakaszok felújítása, így az utak állapotának javítására más forrást kell keresni. A tanulmány egyik fontos konklúziója, hogy a híd feltételezhetően képes mobilizálni a Kalocsai járásban élőket. Érdemes kiemelni a szakmával nem rendelkező munkavállalókat. A híd ezen hatása megegyezik egy nagyobb méretü ipari beruházással, alacsonyabb költségek mellett. Így belátható, hogy a munkahelyteremtés nem kizárólagos alternatíva a munkanélküliség csökkentését illetően. A Paksi és Kalocsai járás a híd megépülése után gazdaságilag homogénebb képet mutat majd, valamint az álláskeresési statisztikák is kedvezőbbek lehetnek a 2015-ös adatokhoz képest.

Egyelőre a híd helyszíne még bizonytalan, ezért ennek változása esetén a modell újrakalibrálása szükséges. Azonban a korábban feltárt fő befolyásoló tényezők így is érvényesek. Újra szükséges kiemelni, hogy a korábban felvázolt hipotetikus modell csak a legvalószínübb forgatókönyv alapján készült el. Az idő múlásával egyre több információ áll a közlekedésfejlesztés iránt érdeklődők számára rendelkezésre, így a modell kisebb módosításával pontosabban prognosztizálhatók az eredmények. Amennyiben az atomerőmü megépítése mégsem valósulna meg, úgy a híd létjogosultsága továbbra is fennáll, hiszen a Paksi járás gazdasági fejlettsége több szempontból felülmúlja Kalocsa térségét. A Duna bal partján élők számára még így is pozitív hatást gyakorolna a híd, amely egyúttal képes lenne aktivizálni a rendelkezésre álló, szabad munkaeröt, elsősorban azokat, akiknek jelenleg nincs lehetőségük a lakhelyükhöz közel, tartósan munkahelyet találni. A híd létjogosultsága, jelentősége tehát (ha hosszú távú megtérülése még nem is látható) ebből a szempontból - az energetikai beruházástól függetlenül - megkérdőjelezhetetlen. A jelen vizsgálatban alkalmazott módszerek egy része a jövőben más, hasonló fejlesztések kapcsán is használható. Ilyenek lehetnek például a Széchenyi 2020as Terület- és Településfejlesztés Operatív Programjához kapcsolódó infrastrukturális beruházok, amelyek a gazdaságfejlesztést és a munkaerő-mobilitás ösztönzését szolgáló közlekedésfejlesztésre épülnek. Ugyanakkor a jelenleginél reálisabb képet akkor kapunk, ha még szélesebb gazdasági és társadalmi, valamint közlekedési viszonylatba helyezzük el a beruházás és a híd jövőbeli együttes szerepét. A közeljövő vizsgálatainak további irányai tehát ebbe az irányba mutatnak.

\section{FELHASZNÁLT IRODALOM}

[1] Alpek B. L., Tésits R. 2014: Egy többváltozós modell definiálása az álláskeresők mobilitási fokának vizsgálatához. Szakképzési Szemle 30 (2): 4-21.

[2] Ehleiter J. 2002: Településirányítás és infrastruktúragazdaság. BKÁÉ Államigazgatási Kar, Budapest, 10-19.

[3] Fleischer T. 1994: Az infrastruktúra-hálózatok fejlesztésének egyes kérdéseiről. (Kandidátusi értekezés), Budapest, 144 p.

[4] Lukács N. 2015: A Paksi atomerőmű bővítésének lehetséges hatásai a térség demográfiai és településfejlesztési folyamataira. PTE TTK FI, Pécs.

[5] Pénzes J., Molnár E., Pálóczi G. 2014: Helyi munkaerő-piaci vonzáskörzetek az ezredforduló utáni Magyarországon. Területi Statisztika 54 (5): 474-490.

[6] Sebők M. 2016: Munkaerő-piaci mobilitás Magyarországon. Edge 2000 Kiadó, Budapest. 18-20.

[7] Tésits R., Alpek B. L. 2013: A leghátrányosabb helyzetü álláskeresők mobilitás-vizsgálatának új módszerei. Humán Innovációs Szemle 4 (1-2): 46-64.

[8] Vámosi T. 2013: Munkaerő-piaci ismeretek (e-learning tananyag) PTE FEEK, Pécs, 2013, 239 p. 
http://mno.hu/migr_1834/nem-kesik-az-autopalyak-epitese-828037

http://www.napi.hu/magyar_vallalatok/a_glencore_40_milliardert_fejlesztett_fokton.564900.html http://net.jogtar.hu/jr/gen/hjegy_doc.cgi?docid=A16H1505.KOR\&timeshift=fffffff4\&txtrefer er $=00000001 . \mathrm{TXT}$

http://www.hidak.hu/konyvek/Duna\%20hidjaink.pdf

http://www.vki.hu/ tfleisch/PDF/pdf93/APOKO930912.pdf

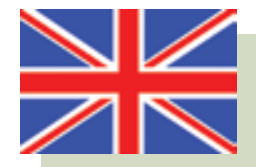

The anticipated influence of the bridge between Paks and Kalocsa planned in connection to the extension of the power plant on the labor market and mobility

The expansion of Paks Nuclear Power Plant and construction of the Paks-Kalocsa bridge should be evaluated in parallel. The study examines the likely impact of infrastructure investment on labor market and mobility in the affected districts. Determining mobility, the study uses a number of methods, the most complex of which is the Average Degrees of Mobility (ADM), These calculations make the settlements comparable to each other on the basis of their objective and subjective characteristics. With the help of the GIS application the research models the waytime distances modified by the bridge between the NPP and the settlements of Kalocsa district. The authors also used a test survey for the $\mathrm{ADM}$ and GIS. One of the main conclusions of the study is that these investments can make the socio-economic picture of the examined districts more homogeneous. The bridge to be built eliminates the isolation effect of the River Danube, thus the expansion of the nuclear power plant can be an alternative for workers living in the Kalocsa district. Based on the empirical research, the renovation of roads in the region can help to maximize the potential of the bridge.

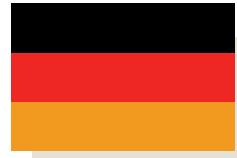

\section{Die erwarteten Auswirkungen auf die Arbeitsmarkt} und die Mobilität der Donau-Brücke zwischen Paks und Kalocsa, die wegen der Kraftwerkerweiterung geplant wird

Es liegt an der Hand, die Erweiterung des Atomkraftwerks ins Paks und den Bau der brücke zwischen Paks und Kalocsa parallel zu bewerten. In dem Bericht es wird untersucht, welche Auswirkungen die-ser infrastrukturellen Investitionen auf den Arbeitsmarkt und auf Mobilität der betreffenden Kreisen ausgeübt werden. In dieser Untersuchungen es werden für die Ermittlung der Mobilität mehrere Me-thoden verwendet, von denen die am komplexeste der Durchschnitt der Mobilitätsgrade (MFÁ) ist. Auf Grund der Berechnungen es kann ein Vergleich der Ortschaften hinsichtlich ihrer objektiven und subjektiven Charakter durchgeführt werden. Durch Anwendung von geoinformatischen Methoden die Forschung kann die durch die Brücke modifizierten Zeit- und Wegentfernungen zwischen dem Kraftwerk und den Siedlungen im Kreis Kalocsa modellieren. Für den MFÁ und für die Aufladung des geoinformatischen Systems es wird in der Untersuchung eine Vermessung mit Hilfe von Fragebo-gen verwendet. Eine der wichtigsten Forderungen ist es, dass durch die Investitionen die gesellschaft-liche-wirtschaftliche Situation der beiden Kreise viel homogener wird. Die geplante Brücke elimi-niert di isolierende Wirkung des Flusses, so bietet die Brücke eine Alternative für die Arbeitsnehmer, die im Kreis Kalocsa leben. Empirische Forschungen zeigen, dass die Sanierung der Strassen in der Region die Ausnutzung des Potentials der neuen Brücke maximieren kann. 